So while there is as yet no clear understanding of the factors controlling liver regeneration, it seems likely to be a multifactorial process with hormone changes playing a major part. Purification of the hepatic regenerative stimulator substance could possibly be of clinical value for increasing the regenerative response in some diseases.

${ }^{1}$ Higgins GM, Anderson RM. Experimental pathology of liver : restoration of liver of white rats following partial surgical removal. Archives of Pathology $1931 ; 12: 186-202$.

${ }^{2}$ Lin T-Y, Lee C-S, Chen C-C, Liau K-Y, Lin W-S-J. Regeneration of human liver after hepatic lobectomy studies by repeated liver scanning and repeated needle biopsy. Ann Surg 1979;190:48-53.

${ }^{3}$ Williams R, Hughes RD, Cochrane AMG, Ellis WR, Murray-Lyon IM. Studies on plasma cytotoxicity and liver regeneration in fulminant hepatic failure. Ciba Found Symp 1978; No 55:299-305.

4 Leduc EH. Regeneration of the liver. IIc. Mechanisms controlling liver regeneration. In: Rouiller C, ed. The liver: morphology, biochemistry, physiology. Vol 2. New York: Academic Press, 1964:69-76.

5 Terblanche J, Starzl TE. Hepatic regeneration: implications in fulminant hepatic failure. Int $\mathcal{F}$ Artif Organs 1979;2:49-52.

${ }^{6}$ Leffert H, Alexander NM, Faloona G, Rubalcava B, Unger R. Specific endocrine and hormonal receptor changes associated with liver regeneration in adult rats. Proc Natl Acad Sci USA 1975;72:4033-6.

7 Terblanche J, Porter KA, Starzl TE, Moore J, Patzelt L, Hayashida N. Stimulation of hepatic regeneration after partial hepatectomy by infusion of a cytosol extract from regenerating dog liver. Surg Gynecol Obstet $1980 ; 151: 538-44$.

${ }^{8}$ Goldberg M, Strecker W, Feeny D, Ruhenstroth-Bauer G. Evidence for and characterisation of a liver cell proliferation factor from blood plasma of partially hepatectomised rats. Horm Metab Res 1980;12:94-6.

${ }^{9}$ Miura Y, Fukui N. Prostaglandins as possible triggers for liver regeneration after partial hepatectomy-review. Cell Mol Biol 1979;25:179-84.

\section{Patient participation: more pipedream than practice?}

Are those enthusiasts who want to spread the idea of patient participation groups in general practice getting their message across to the right people? To judge by a recent conference at the King's Fund Centre it seems not. Representatives of community health councils, area health authorities, the press, and students and lecturers were more in evidence than general practitioners and patients. Moreover, no good evidence was produced that the groups are beneficial, and some people had unrealistic expectations about what they might achieve.

It is now eight years since the first patient participation group was started, and there are still only 32-a drop in the ocean when there are nearly 11000 practices in Britain. Most have been started not by patients but by doctors, and one reason there are so few may be that many general practitioners have not heard of the idea: thus 10 of 15 general practitioners in the north west of England who were responsible for training groups of doctors had not heard of patient participation groups. ${ }^{1}$ Groups have started up to meet the needs of their particular practices and do not conform to any particular pattern. Health centres seem to have the right conditions, but nobody knows why none flourish in single-handed practices. Perhaps a doctor practising alone is more likely to build up close relationships with his patients, and only those who work in and attend large health centres feel the need for a structured group to encourage communication. Nor does anyone know what patient participation groups achieve or even try to achieve. The aims of some are very broad: their accomplishments include helping doctors; looking at how the services are used-for example, whether it is practicable to have an antenatal clinic at $1 \mathrm{pm}$ for working mothers; organising car services to surgeries in areas with poor public transport; and planning health education activities. But they seem unlikely to achieve anything as ambitious as changing the way that doctors behave in individual consultations. The conference heard several speakers argue for better communication between doctors and individual patients, but nobody made it clear what patient participation groups can do about this.

Understandably community health councils are interestedis in what patient participation groups are doing and want to work more closely with them nationally and locally. But the health councils cover large geographical areas and are con cerned with hundreds of thousands of patients, while theo main virtue of patient participation groups is that they work응 locally. Patients work together with general practitioners and $\overline{\frac{\bar{p}}{5}}$ other health staff to improve the services for their own "community" in their own practice. It is surely human nature"s to want to focus on narrow personal interests, but if the idea $\vec{\circ}$ of patient participation really caught on in general practicethe benefit to the larger "community" might be great. The health councils must not expect too much too soon.

So should every practice have a patient participation group ?? Those who have successful groups seem to enjoy them ando be convinced of their worth, but some groups have faded away and some practices have found it impossible to start $N$ them. Also no one has produced convincing evidence of benefit. Nevertheless, Dr John Horder, president of the Royal College of General Practitioners, was convinced of their worth, advocating at the conference that all trainees ino general practice should learn about them and going on to say that this should be added to the college's priorities of prevention? and audit.

1 Wood J, Metcalfe DHH. Professional attitudes to patient participation groups: an exploratory study. $\mathcal{F} R$ Coll Gen Pract 1980;30:538-41.

\section{Death of a quango}

Quangos are not popular, so ministers run little risk of disapproval when they kill one off. If the quango is a minor one-a mere subcommittee-its demise is unlikely to be newsworthy. Yet one such subcommittee, which has recently been eliminated by the health and agriculture ministers, deserves at least a 3 decent obituary and perhaps even an attempt to find a way of $\delta$ performing the functions intended for it but never made possible.

The quango in question was the Joint Sub-Committee on Anti-microbial Substances. It was set up as a result of recommendations made by the Swann Committee, ${ }^{1}$ which was created because of concern that the use of antibiotics for promoting growth in animal husbandry without proper veterinary supervision might produce a great reservoir of antibiotic- $\omega$ resistant bacteria which would prejudice the use of antibiotics as therapeutic agents for man and animals. The relevant $\frac{\mathbb{\Phi}}{\stackrel{D}{0}}$ recommendations were ". . . that one committee should have $\stackrel{\oplus}{+}$ overall responsibility for the whole field of use of antibiotics $\frac{T}{7}$ and related substances whether in man, animals, food preser- $\frac{O}{\mathbb{D}}$ vation or for other purposes . . . and that this committee should $\stackrel{\odot}{\mathbb{D}}$ be empowered to demand, on a basis of confidentiality, such $\varrho$ returns as it considers to be necessary." The Swann Report and its recommendations were blessed by the Labour Govern- 8 ment in 1969 and by the Conservative Government elected 
in 1970. There was worldwide interest in the Swann Report, some agreeing, some disagreeing, but all wanting to know the outcome of what looked like a serious attempt to understand and possibly limit the spread of antibiotic resistances among bacteria.

Alas for good intentions and hopes, however: what legislation brought into existence in 1973 was not the powerful committee recommended by Swann but a joint subcommittee of the Committee on Safety of Medicines and the Veterinary Products Committee. The two parent committees were concerned mainly with applications from pharmaceutical firms for product licences and test certificates. In practice, the Veterinary Products Committee consulted the Joint SubCommittee on Anti-microbial Substances a great deal while the Committee on Safety of Medicines used it very little. Occasionally others also consulted the Joint Sub-Committee on Anti-microbial Substances on matters affecting the use of antimicrobials as pesticides, food additives, and decontaminants. Practically all the subcommittee's work, however, was in advising the Veterinary Products Committee on applications to introduce new antimicrobials or variations of old ones. Attempts by the subcommittee to secure information from the pharmaceutical industry about the amounts of antibiotics used in human and veterinary medicine and in animal husbandry ended in frustration. Time was never found to legislate to make it compulsory to disclose the information requested, even in confidence. With the encouragement of the Joint Sub-Committee on Anti-microbial Substances, individual members did valuable work on a personal basis with pharmaceutical firms, specifically in helping to clear up ambiguities and shortcomings in applications submitted. But the subcommittee itself could not contact firms direct because it was in a subordinate position; it was there to advise, not to decide, and appeals against decisions of either of the parent committees might have been complicated by direct contacts if these had led to matters agreed between applicants and the joint subcommittee being viewed differently by the parent committees.

The main weaknesses of the Joint Sub-Committee on Anti-microbial Substances, however, were twofold. Firstly, it had no powers to review the effects of antibiotics already approved. Secondly, it had no resources to commission field studies on a sufficient scale to monitor resistances or to have laboratory findings checked when applications to introduce a new antimicrobial agent or a new use of an existing one left room for doubt about the validity of the conclusions presented. Despite evidence gathered by the subcommittee, some firms continued to advertise in the farming press in a way that clearly encouraged farmers to have certain drugs given to their animals either by pressing their vets to try them or, more probably, securing supplies by their own ingenuity. Doubt remained about how serious the problem of antibiotic resistance really was and whether the best solution was to mount educational campaigns against overuse of antibiotics by both doctors and vets.

Dissatisfied with the uncertain value of its own considerable and careful work-and the lack of powers and resources to do its intended job-the Joint Sub-Committee on Anti-microbial Substances made detailed proposals for its reform and for new terms of reference. After long discussions these were submitted to ministers, whose quick and dismaying reaction was to disband the subcommittee. Admittedly, they added two wellqualified and eminently suitable microbiologists to the Veterinary Products Committee. But that hardly meets the real requirement, well stated by $\mathrm{J} R$ Walton's letter in the Veterin- ary Record" as, "A small group of people with expertise in agriculture, public health, veterinary medicine, bacterial genetics, and clinical medicine." Walton considered that such a group would need access to laboratory facilities; would need to be provided with data on antibiotic use and prevalence of antibiotic resistance; and should be able to develop a close working relationship with the pharmaceutical industry.

Walton is pessimistic in concluding that such a proposal will "never get past first base." Certainly the drastic response of ministers to the subcommittee's own proposals justifies pessimism, especially with the present shortage of Government spending on real investment and especially on medical education and preventive medicine. But there are perhaps some possibilities. The laboratories of the Public Health Laboratory Service and the Veterinary Service at Weybridge supplied the Joint Sub-Committee on Anti-microbial Substances with essential evidence of multiple resistances in salmonellas again spreading by an epidemic in calves, the resistances being induced by trimethoprim. Thus the laboratory skills and interest are not lacking. Individual microbiologists also have added valuable evidence in papers published in this and other journals during the past few years. Surely the public interest and concern must also be that of the pharmaceutical industry. It should not be beyond the capacity and good will of those concerned to get together a group of people to work out the details of a better approach than that embodied in the Joint Sub-Committee on Anti-microbial Substances-one that would justify the expenditure required to supplement what already exists in the Public Health Laboratory Service and at Weybridge.

The ministers have killed their quango. No doubt they will win the love of the Treasury for their further "act of madness" - a familiar, well-justified phrase. Now they should shake their consciences and look for the right way to supplement their unwisely withheld resources. Antibiotic resistances are worth serious and continuing study lest by their spread they extinguish the usefulness of therapeutic antibiotics.

1 foint Committee on the Use of Antibiotics in Animal Husbandry and Veterinary Medicine. London: HMSO, 1969:12.16 and 12.17 (Cmnd 4190; Swann Report.)

2 Walton JR. Advising on antimicrobials. Vet Rec 1981;108:366.

\section{Painful iceberg}

Every doctor knows (or should know) that the most common cause of recurrent abdominal pain is the spastic colon or irritable-bowel syndrome. But how common is this syndrome in the general population? And do all sufferers complain to their doctors, or is there an iceberg of undiagnosed disease? Until recently no figures had been available to answer these questions, but now a survey carried out mainly in Bristol has gone some way to filling the gap. ${ }^{1}$ A total of 301 apparently healthy adults of both sexes and all ages answered a detailed questionnaire, mainly about abdominal pain and bowel habits. No fewer than one-fifth admitted to recurrent abdominal pain in the previous year. In two-thirds of these (14\% of the total) the pain was relieved by defecation, which strongly suggests that it was colonic. Similar pains may be felt by people with colitis or carcinoma of the colon, but these serious diseases 